\title{
A New Approach to the Use of Translation in the Teaching of L2
}

\author{
Roberto A. Valdeón García \\ Universidad de Oviedo
}

\begin{abstract}
The traditional Grammar-Translation method has been replaced in recent decades by the communicative method, which focuses on the importance of the students' oral skills and their ability to be understood by native speakers of the language they are studying. However, this method has now come under scrutiny as more teachers become aware of the need of combining the ability to communicate with a more traditional approach which enables students to attain a good command of L2. Thus, traditional exercises can be revised and updated to achieve this objective. The translation exercise is one of these. In this article we provide the reader with a general view of translations as a teaching method, followed by a study of three texts and some ideas to make this exercise more appealing.
\end{abstract}

\section{An introduction to the use of translation in the teaching of L2}

Translation has been used as a method to teach languages for over two thousand years (Rivers 28). It is still widely used in the teaching of classical languages, Latin and Greek, and it was also used in the teaching of modern languages, as Larsen-Freeman points out. Kelly (151-54) and Titone (27-29) provide us with a historic account of the use of translation as a teaching method. Larsen-Freeman examines eight different approaches to the teaching of second languages and starts with the so-called "grammar-translation method." Maley reminds us of the clear relationship between grammar and translation in his introduction to Duff's book on Translation: "Translation has long languished as a poor relation in the family of language teaching techniques. It has been denigrated as 'uncommunicative,' 'boring,' 'pointless,' 'difficult,' 'irrelevant' and the like, and has suffered from too close an association with its cousin, grammar. Along with its cousins literature, dictation, vocabulary, reading aloud, etc. it has been pushed into the methodological room" (Duff 3). Larsen-Freeman has analysed some of the principles of the translation exercise, showing that this author was not particularly fond of this approach 
and considered it an isolated method, obviating new methods and possibilities or a combination with other more modern approaches (Larsen-Freeman 9-15).

Rivers is equally dismissive and some of her assertions might correspond to the traditional use of translation. It would be correct to say that advanced students of $\mathrm{L} 2$ would benefit from the use of this exercise more than beginners. However, short translation exercises could be introduced at an early stage so that students become familiar with notions of correctness and propriety rather than avoid them altogether in an attempt to encourage a communicative approach which obviously tends to boost communicative competence, but obliterates other aspects of the learning process. Some of the drawbacks in using the translation exercise mentioned by Rivers are that the students are given little chance to practice the target language and this results in confusion when the students are addressed in the language they are learning (30). Another negative point she makes is that translating "is not too demanding on the teachers; when they are tired, they can always set the class a written exercise" (31). Some of these points are open for discussion and we will attempt to provide a new dimension to this biased account of the translation exercise.

The truth is that other authors have given similar views in favour of a more communicative approach, which would rely more on the student's output and the necessary given situations to obtain the message than on notions of correctness. As a result, the translation exercise might be discouraging for students (Rivers and Temperley 18) and, as previously stated, it might be argued that it makes few demands on teachers (Richards and Rodgers 4). An ability to communicate is prized over the acquisition of linguistic structures or vocabulary. Therefore, the focus is placed on communicative activities and the advocates of this method merely concentrate on the language as a means of communication. As Harmer says "Its aims are overtly communicative and great emphasis is placed on training students to use language for communication" (41). Conversely, the more traditional approach is reputedly based on the teaching of grammar and the application of the knowledge on exercises. Thus, students would be required to memorize a great number of rules together with the necessary vocabulary to use those rules. But the whole process would take place out of context, outside real situations in which students might need to resort to their second language. These two apparently opposed sides have given way to a wide controversy over which method might benefit students most. Thus, in the 1980s we witnessed one of the most impassioned debates between Swan and Widdowson. However, it is not our aim to discuss which approach is preferable. Our main interest is to try to see if the traditional translation exercise can help both teachers and students in our common teaching-learning activity, in an effort to reconcile two seemingly extreme positions.

After dominating the language teaching scene for well over a century (from the $1840 \mathrm{~s}$ to the 1940s) translation has played a secondary role in recent decades, although it has still been used despite the communicative trend. In recent years there have been some signs that translation could be making a come-back. Duff's book on translation is one of them. Duff strongly supports the view that translation is an excellent means of improving one's language because it invites speculation and discussion. Other advantages of translation are that it helps students develop three essential qualities: accuracy, clarity and flexibility and that students can see the link between grammar and usage (Duff 7). Furthermore, 
translation can also be an appropriate technique to introduce new words (Harmer 162) or even to explore the obscure nuances between terms.

\section{A study of three relevant cases}

In this article we are going to examine the usefulness and validity of translations as a way of prompting the learners' self-awareness of their own limitations in the decoding process of written messages and subsequent rendering into a second language. We shall now make the traditional distinction between translation and prose exercises. This differenciation is a relevant starting-point since we are going to analyse three texts and the English versions produced by our students in an attempt to draw possible conclusions. Therefore we will be dealing with prose exercises, that is to say, translation from the learners' mother tongue into L2. The students who worked on the texts were supposed to have attained a Proficiency level by the time they produced their versions. They had done a phonetics course and three university courses of English language. They were, consequently, advanced students. The three texts that we chose were extracts from literary works, two contemporary novels and a short story. The texts had been adapted to avoid unnecessary difficulties (the advantages and disadvantages of using adapted material will be obviated in this article). We shall reproduce each text followed by a grid of the main mistakes made by the students. We will make no distinction between types of errors for our purposes and, therefore, we will obviate any previous distinction between types of mistakes. Some researchers have spoken of errors caused by fatigue and inattention, or "performance" errors, and of errors which stem from a lack of knowledge of the grammar or "competence errors" (Chomsky, for example), while others have distinguished between "errors" and "mistakes" (Corder 163) and the list could continue (Jenner, Bell); however, we will use either name to refer to any deviation from the established language rules.

\section{Text 1}

Me volví hacia Rosario. Ella me miraba con desdén, con cierta gravedad irónica que no sabía como interpretar. Quise iniciar una conversación cualquiera que nos alejara de lo sucedido, pero las palabras no me venían a la boca. Mouche, mientras tanto, se había acercado al griego con una sonrisa tan provocadora y nerviosa que la ira me encendió. Apenas habíamos salido de un percance que hubiera podido tener consecuencias lamentables, y allí estaba ella tratando de seducir al minero que la tratara media hora antes como a una prostituta. Esa actitud era tan literaria que la hallé increíblemente grotesca en su incapacidad para desasirse de los estereotipos de su generación.

La miré de modo tan extraño que Rosario, creyendo tal vez que iba a pelear de nuevo por celos, me salió al paso con una frase que tenía algo de proverbio y algo de refrán: "Cuando el hombre pelea, que sea por defender su casa." No sé lo que entendía Rosario por "mi casa"; pero tenía razón si pretendía decir lo que quise comprender: Mouche no era "mi casa." Era, por el contrario, aquella hembra alborotosa de las Escrituras, cuyos pies no podían estar en casa. Con la frase se tendía un puente de comprensión entre Rosario y yo, y sentí, en aquel 
momento, el apoyo de una amistad que se hubiera dolido, tal vez, de verme vencido nuevamente. Mouche, en cambio, se tornaba, poco a poco, en algo ajeno, excéntrico, que llamaba la atención, como llamaba la atención antaño, en las cortes cristianas, el turbante de los embajadores. (Text was adapted from Alejo Carpentier's Los pasos perdidos)

\section{Table to text 1}

\section{MiSTAKE (Number of occurrences)}

looked me down (8)

looked me with dirty (2)

in disdain (5)

interprete, interpretate (27)

took away of (12)

approached to the Greek (15)

greek (11)

Greek man (36)

she was there (27)

actitude (26)

so a strange way (27)

gazed her (3)

in/by/for jealousy (21)

because of my jealousy (27)

jealous (15)

something a proverb (24)

addressed to me (27)

for defending (12)

understood for/meant for (22)

pretended (24)

for the contrary (23)

comprehension (32)

in that moment (39)

hurt (15)

for seeing me beaten (12)

at seeing me beaten (12)

little to little (3)

that (4)

reign, kingdom, castle (8)

\section{CORrect Form}

looked down on me

looked me with disdain

with disdain

interpret

took away from

approached the Greek

Greek

Greek

there she was

attitude

such a strange way/so strange a way

gazed at her

out of jealousy

because I was jealous

jealousy

something of a proverb

addressed me

to defend

understood by/meant by

intended

on the contrary

understanding

at that moment

suffered

to see me defeated again

to see me defeated again

little by little

which

court

We collected 97 written English versions of the Spanish text provided to the students. The order of the mistakes in this grid, as well as in the remaining two, follows the Spanish text. We have included all those mistakes that we have judged relevant enough, either for the number of times that were made or because we had not expected to encounter them at this stage. The three texts that we have chosen present a variety of mistakes that we have attempted to classify for practical purposes. The classification will be arbitrary (as all classifications are, Cohen 113, Richards and Rodgers 155). The first conclusion that we 
may reach is that our students find it difficult to use the vocabulary they have acquired over, at least, a period of three years. The first error provides us with sufficient evidence: the Spanish expression "me miraba con desdén" has been rendered a "looked me down" instead of "looked down on me." The students were familiar with a phrasal verb and were aware that English tends to use phrasal verbs rather than Latin-rooted verbs. Still they omitted one of the particles and, accordingly, altered the verb/object order. The result is a change in meaning and the message of the original sentence is lost. More surprising is the use on two occasions of the expression "looked me with dirty," which does not correspond to the Spanish meaning and which breaks the rule as to the use of prepositional phrases (Quirk et al. 657ff). The confusion noun/adjective also took place in "jealousy" "jealous."

Similar deviation from the original meaning occurred in three more cases. The main difficulty with the word "comprension" is that the English language has a similar word that is used in different contexts. This is a common feature of the translation exercise. Students resort to the familiar words, that is (a) words that they have heard or read before or (b) words that they might infer from another term existing in their own language.

The risk with these two options is that they might use those terms in the wrong context or they might just coin new words or phrases. A good number of our students was tempted to use "comprehension" instead of "understanding" in our first text. The same occurred with "pretendía," which was translated as "pretended" instead of "intended." Another mistake with semantic connotations, although with no equivalent Spanish form is "dolido," which became "hurt" instead of "suffered."

The interference, or influence, of Spanish spelling can be noticed in the use of words such as "interpretate" or "interprete" for "interpret," thus obviating the resulting changes in the pronunciation of this word if it were spelt in either of the ways proposed by the students. The last example to be mentioned in this category is "corte," which gave way to a variety of versions: "reign," "kingdom," "castle," etc. It would be logical to think that this mistake stems from the fact that the student is not familiar with the word "court," in spite of its close relationship to the Spanish term, but we must take into account that our students have already done English history and, therefore, must have read or heard the term before. At any rate, the confusion between the four terms seems rather curious to us, since the English and Spanish terms have an identical meaning.

The second important category that we identify in our list is that of prepositions. These can be subdivided into two groups: (a) the use of a preposition when it is unnecessary in English, or vice versa; (b) the use of the wrong preposition.

As regards the first subdivision, our students tended to use prepositions as complementation of verbs (Quirk et al. 709) when not required. Thus, we read "approached to the Greek" or "addressed to me" where both prepositions are wrong, and, although some authors, like Corder (Error Analysis), have dismissed the interference of the mother tongue in L2, the influence of Spanish is clear in examples like those we have just quoted ("acercarse $a$ alguien," "dirigirse $a$ alguien") or, quite the opposite in a case like "gazed her," where the preposition "at" has been omitted, as in Spanish.

Spanish has also clearly influenced the choice of preposition in the cases of our second subdivision, such as "in that moment" instead of "at that moment," "for the contrary" 
instead of "on the contrary," "little to little" instead of "little by little," etc. Or, otherwise, the existence of two prepositions for one in Spanish has also caused confusion: "understood for/by."

Our next category deals with syntactic mistakes. Our students translated "de modo tan extraño" into "so a strange way," thus mixing the two English constructions indicated in the table. And they also omitted the use of the article in "something of a proverb" because Spanish does not take it ("algo de proverbio").

The final category that we shall mention is that of spelling mistakes: the typical smallcase letter for "Greek" and, once again the influence of Spanish in "actitude," reproducing the Spanish "c" instead of an English "t."

The second text that we propose in this study of error analysis is as follows:

\section{Text 2}

José restauró el dormitorio de su mujer, mandó limpiar y remendar las cortinas de terciopelo de la cama de madera, y puso otra vez en servicio el baño abandonado. A esos dos lugares se redujo su imperio de pacotilla, de perfumes falsos y predería barata. Lo único que le disgustó en el resto de la casa fueron los santos del altar doméstico, que una tarde quemó hasta convertirlos en ceniza, en una hoguera que prendió en el patio. Dormía hasta después de las once. Iba al baño con una antigua y deshilachada túnica de dragones dorados. A los pocos días de llegar, abandonó el traje que llevaba puesto, que además de ser demasiado caliente para el pueblo era el único que tenía, y lo cambió por unos pantalones muy ajustados, muy parecidos a los que usaba Pietro Crespi en las clases de baile. Dos veces por semana lavaba la muda completa, y se quedaba con la túnica hasta que se secaba, pues no tenía nada más que ponerse. Nunca comía en casa. Ni se le hubiera ocurrido hacerlo. Salía a la calle cuando aflojaba el calor de la siesta, y no regresaba hasta muy entrada la noche. Entonces continuaba su deambular angustioso, respirando como un gato, y pensando en su mujer. Ella, y la mirada espantosa de los santos, eran los dos recuerdos que conservaba de la casa.

Casi un año después del regreso a casa, había vendido para comer la cubertería de plata. (Text from García Marquez's Cien años de soledad)

\section{Table to text 2}

\section{MiSTAKE (Number of occurrences)}

rearranged/renewed (7)

he had the velvet curtains to clean (5)

It was reduced to these two places

his false empire (7)

reducted (6)

A few days later of his arrival (5)

he left the suit (17)

antic, antique (9)

a very tight trousers (8)

taut/fit/narrow/tied (13)

\section{CORRECT FORM}

restored

he had the velvet curtains cleaned

His false empire was...

reduced

After arriving/his arrival

he took off the suit

old

very tight trousers/a very tight pair ... tight 


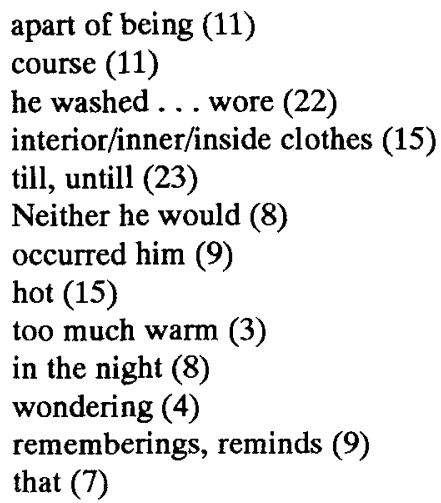

apart from being
class, lesson
he would wash ... wear
underwear
until
Neither would he
occurred to him
heat
too warm
at night
wandering
memories
which

We collected 76 English versions of the text. These mistakes do not quite fit into the division that we have used for our first text, but we can modify it slightly to achieve an overall view. The students' versions provide us with a good number of errors whose main characteristic is a semantic deviation from the original; thus, some students rendered the second word of the Spanish text, "restauró," as "rearranged" or "renewed," which do not quite correspond to the meaning of the Spanish term, but which, however, are related. The cases of "reducted" and "reduced" or "rememberings/reminds" for "memories" are similar.

Conversely, other semantic errors do not have such a basis for confusion. Rather strikingly, a good number of students do not seem to see the difference in meaning between "course" and "class" or "lesson" and, in consequence, use the former to translate Spanish "clases" into English. Some still confuse such pairs as "wondering" and "wandering," almost homophonous, except for the first vowel, but with very different meanings.

The difficulty of translating "viejo" into English can be easily tested in this text, with the appearance of several possiblities, "antique," "antic," "ancient," all of them wrong in the context provided, and the second unrelated to the other two.

The three extreme cases are "abandonó el traje que llevaba puesto," "unos pantalones muy ajustados" and "la muda completa." Some students did not realize that the author used "abandonó" in a very literary style, which cannot be translated into English literally. Thus "abandoned his suit" is definitely wrong; they should have resorted to the more common "took off," which loses the strength of the Spanish original, although it clearly conveys the message. We, as teachers, not as translators or as teachers and translators, must be aware of the fact that this loss is important, but in no way fundamental. The aim of the exercise is not to produce English texts of similar literary standards to the original, but to allow our students to practise their knowledge, to become conscious of the mistakes and, consequently, to make progress in their learning process. The exercise will have a double benefit if it also fosters discussion on the use of the language and the differences between L1 and L2, but we must not attempt to overdo its aim.

The other two mistakes are also significant. "[P]antalones ajustados" has had an interesting variety of possibilities, "taut," "fit," "narrow," "tied," all of them wrong, even though the correct adjective is of common use. And finally, we might clearly infer that 
Spanish has again influenced our students, since they related "muda" to "ropa interior" and rendered it as "interior clothes," "inside clothes" or the more comical "inner clothes."

In our next category we find some overlapping with semantic mistakes. Spanish use might have influenced the confusion between "hot" and "heat" (in Spanish "hace calor," in English "it's hot"). Thus they have nominalised an adjective and have written "the hot of the siesta/the afternoon hot" for "the heat of. ..." The same applies to "too much warm" were the adjective is premodified as if it were a noun (Quirk at al. 1140ff.).

As regards prepositions, the students encountered fewer difficulties in this text. However, we have examples of the two subdivisions that we have already commented for our first text:

a) "It occurred him," omitting the preposition "to"

b) "Apart of being" instead of "apart from being"

The last category that we shall mention for this second text is that of syntactic errors. They are abundant and they range from the use of unnecesary double subjects ("It was reduced to these two places his false empire") to the use of wrong tenses. The former reproduces the sentence order of the original and, consequently, they have added a subject to the verb "was" rather than altering the order and placing "his false empire" at the beginning. The latter is the case of those sentences which would prefer a modal "would" to express "habit" rather than a past tense. Yet, the students translated "lavaba la muda completa y se quedaba con la túnica" literally "washed ... and wore" instead of "would wash ... and would wear."

Our third text was the following:

\section{Text 3}

La historia conocida de Alcalá del Júcar empieza justamente cuando el rey cristiano Alfonso VIII toma el castillo a los conquistadores árabes en la primavera de 1211. El pueblo va creciendo entonces y consigue primero su independencia; pasa de las manos de un aristocrata a las de otro-fue incluso propiedad de los Reyes Católicos-y el suceso más importante de su recoleta vida, también el más dramático, fue sin duda la ocupación que sufrió por las tropas carlistas en el verano de 1835: los soldados "corrieron sus calles, derribando las puertas de sus casas, saqueando y pegando fuego donde mejor les parecía; impusieron una exorbitante contribución y el alcalde se fugó por no poder pagarla, excusando así el haber sido fusilado," dice un testigo de la época.

Sin duda, la razón de la importancia de la villa en tiempos pasados (tenía casi 3.000 habitantes a mediados del siglo XIX) se debió al hecho de estar situada en el Camino Real entre Castilla y Levante, con Aduana y cuartel militar para defender el paso. Un sólido puente medieval, al que suelen llamar romano, como a casi todos sus semejantes, nos conduce a su interior. El espectáculo desde cualquiera de los caminos que llevan al pueblo es una sorpresa inquietante. Bajo la mole del altísimo castillo y en torno a la iglesia -que se diría otro castillo- las casas predominantemente blancas parecen pegadas al terreno, como animales desesperados. (Text adapted from a short story in the Mediterranean magazine) 


\section{Table to text 3}

\section{Mistake (Number of occurrences)}

history (17)

Alfonso the eight/Eight (15)

Arabian/Arabic (16/8)

conquistadores (3)

1,211/1.211 (4)

independency (16)

it was even property (16)

Catholic Kings (64)

Reyes Católicos (2)

the more important (4)

run (35)

major (21)

$3.000(12)$

XIX (7)

Camino Real (5)

Castilla (40)

Real (7)

costums (4)

frontier, barrier, adouane (35)

militar (7)

into the interior (9)

show (9)

frightening (14)

tall (4)

as desperate animals (11)

that (11)

roman, arab, catholic, christian ... (48)

\section{CORRECT FORM}

story

Alfonso VIII

Arab

conquerors

1211

independence

it even belonged to

Catholic Monarchs/Majesties

Catholic Monarchs

the most important

ran (or "runs")

mayor

3,000

19th century

Royal Way

Castile

Royal

customs

customs

military

inside the village

spectacle/spectacular view

disturbing

high

like desperate animals

which

Roman, Arab ...

The number of collected versions was 91 . The main difficulties that arose in this text differ considerably from our previous texts. A great number of mistakes could be described as formal mistakes, since the students have not acknowledged differences of spelling, differences in the writing of figures and years, the existence of English versions of Spanish words, etc. The number of these mistakes is highly relevant and must be stressed. Over $50 \%$ of the students made some spelling mistakes as regards the capitalization of such nouns as Christian, Catholic, Roman and Arab. Around 17\% believed that Alfonso VIII should be written as it is pronounced, avoiding the Roman numerals. Conversely, Roman numerals were used to render "XIX" into English, even though English avoids them for centuries.

Another important characteristic of these versions was the confusion as to when to write a comma or a decimal point in figures. We need neither for years; as regards other figures, we must bear in mind that they are placed the other way round if we compare them to Spanish (e.g. 3.000 in Spanish, 3,000 in English). 
In other cases, the students were reluctant to use English nouns for Spanish names, which are normally used in English: Castile, and not Castilla (although almost 50\% chose the latter), Catholic Monarchs instead of Reyes Católicos and so on. There was another common mistake when translating this phrase. Two thirds of the students wrote "Catholic Kings." It is true that, at one time, English history books referred to Queen Isabella and King Ferdinand as the Catholic Kings, probably due to literal translation from Spanish. This translation is now avoided, undoubtedly influenced by the wave of political correctness coming from the other side of the Atlantic, and, therefore, most history books call them Catholic Monarchs or, more pompously, Catholic Majesties. This zeal to stick to the original gave way to some clear semantic errors such as rendering "Camino Real" as "Real Path" or leaving "conquistadores" as it is: the latter is also used in English, but when referring to Spanish conquerors in South America.

Therefore, the text is rich in names and figures which would help our students to revise spelling rules as well as to discuss the existence of English versions of Spanish names which should be used, in the same way we speak of England, not of "Inglaterra." It is a constant feature of our students to encounter some reluctance to pronounce the names of Spanish cities or regions in English. Thus our students, even the most advanced ones, tend to have a good British pronunciation and come up with the occasional Madrid, as in "Madriz," or Sevilla, in the middle of a class.

But there were other semantic errors of the same type as in our previous texts: Spanish has prevailed in the rendering of "independencia" as "*independency"; they had difficulties translating "aduana" and came up with "frontier" or "barrier"; they confuse similar words in spelling such as "major" "mayor" or "history" /"story"; "espectáculo" became "show" even though the context clearly requires a different term.

We also found an important number of morphological mistakes. Some students were unable to use a common irregular verb correctly, "run." Thus, although most verbs were in the past tense, some students used "run" following a third person singular. We must infer that they have not yet assimilated the three forms of the verb "run" or, otherwise, they have omitted the "-s" for third person singular verbs in the present tense. Another important mistake was the use of "the more" for superlatives in a few cases.

Finally another mistake, which is a common feature of all three texts, is the confusion between the use of the relative "that" and "which" (see the three tables provided).

\section{Proses in the classroom: their purpose}

We have been examining three texts and the errors made by the students in their versions. Now that we have reached this point, we might wonder what conclusions we can draw from our study. As teachers of English, we are interested in using this insight into our students' mistakes to improve our teaching activity and to focus on the needs of the students. Explanations as to why some students make these mistakes while others do not are irrelevant, despite some authors' interest in classifying possible reasons (Bell 171-72). However, what seems clear to us is that students are clearly influenced by their mother tongues and, consequently, we should take this factor into account when attempting to 
correct their habits. The contrastive analysis of errors had its heydey in the 1950s and underwent a decline in the following decades. Some of its principles are still relevant for modern teachers of L2, particularly if they are also speakers (native or non-native) of the students' mother tongue. The teacher can be assisted by this extra knowledge, as pointed out by Lado (9) and more recently by Piñel and Moreno.

The classification of errors that we proposed can be complemented with others (Corder, "Error Analysis" 64; Dulay, Burt and Krashen 138-98; Hubbard), but the relevant point to be learnt is that not only students can learn from their mistakes, their teachers can also gain further insight into what their students' difficulties in coping with L2 are and how to solve them. Svartvik had already pointed out that "by locating error ... pupils learn to learn and teachers learn to teach" (9). We might argue that this view is somewhat extreme. Teachers do not learn to teach by locating errors, since, quite obviously, most teachers can locate errors and correct them. However, by becoming aware of their students' errors, teachers can develop positive strategies of error correction which will enable students to make progress without feeling guilty about their mistakes.

The main barrier that we must overcome when using such an exercise as translation in the classroom is the tendency to correct the students' versions (Doff 192-96). They should be encouraged to do their own correction work rather than expect us, teachers, to play the role of an orchestra conductor. The texts that we have presented were used as the translation paper of final examinations in our university, therefore, the tables of students' errors were drawn from those written versions where the students were not given the opportunity to self-correct themselves.

Nevertheless, the same texts can be used and, as a matter of fact, have been used in the classroom. It is at this point that we must emphasize the importance of the translation exercise. Some of the arguments against the use of translation as a method to teach L2, which we mentioned in the first part of this article, focused on the fact that the students could not practice their target language and, besides, a translation, or a prose for the matter, was not too demanding an exercise on the part of teachers. Our experience shows that both statements can be completely wrong.

First we must do away with the traditional assumption that a teacher could easily resort to a prose or a translation whenever he/she felt tired or had nothing else to do. An exercise of this type does not have to be done in the classroom. Students can work on a given text either individually or in groups so that the actual preparation does not take up any class time. This can also prompt students to work in groups outside the classroom, which would be beneficial as a warm-up pre-class experience. They will be forced to look at the text as a message that needs to be conveyed to other speakers of L2.

Once the translating process has been carried out outside the classroom, the students will expect their work to be corrected or, at least, improved. Thus the teacher must be ready to tackle all the possible questions that might arise. The traditional view that this exercise was not too demanding could now be reversed as not all teachers may have the ability or knowledge (or even time) to be exposed to his/her pupils' questions. He/she will have no difficulties in correcting students who have translated "alcalde" as "major" or "el más importante" as "the more important." There are precise rules and meanings for these cases. But he/she must also be ready to clarify other trickier difficulties, eg if the word 
"viaje" is used in a text, how can we render it into English? As "trip" or "journey"? He/she might even have greater difficulties if someone suggests "travel" or "voyage" (Swan, "Language Conundrums" 332-33). Thus the teacher must have prepared his/her class carefully to meet his/her students' needs and expectations (and to avoid feeling exposed, in the case of those teachers who might not feel too self-confident: thus the exercise could even become too demanding, clearly opposing the traditional view on translations and proses).

However, the main challenge for a teacher who is interested in allowing his/her students to take an active part in the class is the way to achieve this aim with a translation or prose exercise. We have already mentioned the importance of the work carried out outside the classroom. Once the class has begun, the teacher might ask two volunteers to write their versions on the blackboard. In the case of a group of shy students, the teacher might choose the two students who are to write on the blackboard. And the number is essential: the blackboard must be divided into two parts and two students must write their own versions of the same text. We do not need to have all the text written on the blackboard at a time.

Next the teacher must encourage the rest of the class to look carefully at the English versions that their classmates have produced. They can compare the two texts, and with their own, and try to decide which version is more accurate and on which grounds. The two students working at the blackboard must also take part in the decision-making activity: they must not feel that they are being used as mere instruments but as full participants in the exercise. Thus, self-correction is being prompted. If one of the students has used Roman numerals for centuries, the other will most certainly point out the difference and justify his/her own version. They must feel that they are learning, even learning to correct themselves or to revise their own knowledge.

In other cases, both versions could be wrong and some other student may be willing to "suggest" a different version. This will be done tentatively, so as to avoid offending other classmates, but it must be taken as an excellent starting-point for further discussion, on that occasion or in classes to come. To conclude the exercise, the students can be provided with a "correct" version of the translation on the over-head projector so that they have an overview of the whole text.

Thus, the main purposes of our prose exercise could be summarized as follows:

a) Students are encouraged to work individually or in groups, outside the classroom. They learn that they do not need to be constantly guided in their learning process.

b) They are required to produce their own versions of a given text and to defend their options or, otherwise, realise that they have made mistakes. This will obviously involve a speaking activity, which will be more natural than a mere role-play situation.

c) They will learn to accept that they make mistakes before their classmates. This applies to the whole class, even to the teacher, and, consequently, the negative connotations that the term "mistake" usually has could be, at least partially, forgotten.

d) They revise their own knowledge and put it into practice, either through the written version or through an open discussion with other students. At an advanced level, it is particularly interesting to discuss the reasons why one should a present continuous instead 
of a present simple in English, or how we can render a Spanish past simple of the type "Nunca comía en casa," which we have found in the second text.

e) The teacher does not need to assume the scholarly role that seems to be associated to the translation exercise. He/she can take part in the discussion as to which the best option is, providing the students, of course, with new possibilities and encouraging them to reflect upon the best version and the reasons for a particular choice ("frontier," "barrier" or "customs"?).

f) The teacher also has the possibility of choosing the right texts for the exercise. A combination of modern literary texts, with press reports or even instructions to use a videorecorder will make the exercise varied and interesting and his/her students will not feel that they are translating their grandparents' speech, but their own and will appreciate the uselfulness of the exercise.

To prove the usefulness and validity of the translation exercise in the teaching of L2 has been the aim of this article. We started with a general view on the grammar-translation method and continued with a study of students' errors when translating into L2, and how this insight into our students' needs serves us purpose of improving our teaching standards. Finally, we have suggested a way of adapting the exercise to the classroom, so that our students benefit from it from the very moment they start working on the text. We will conclude with Duff's words: "All language is relevant to translation-all styles and registers of both speech and writing. Translation need not be confined to literature! ... to increase the students power and range of expression." Translation will certainly do this" (6-7).

\section{Works Cited}

Bell, R. T. An Introduction to Applied Linguistics: Approaches and Methods in Language Teaching. London: Batsford Academic and Educational, 1981.

Bueno González, A. "Marco de referencia para el análisis de errores." Revista Española de Linguística Aplicada 8 (1992): 41-73.

Chomsky, N. Aspects of the Theory of Syntax. Cambridge: MIT, 1965.

Cohen, A. Testing Language Ability in the Classroom. Rowley: Newbury House, 1980.

Corder, S. P. "The Significance of Learners' Errors." International Review of Applied Linguistics 5 (1967): 161-70.

. "Error Analysis, Interlanguage and Second Language Acquisition." Language Teaching and Linguistic Abstracts 8.4 (1975): 201-18.

Doff, A. Teach English: A Training Course for Teachers. Cambridge: Cambridge UP, 1988.

Dulay, H., M. Burt, and S. Krashen. Language Two. New York: Oxford UP, 1982

Harmer, J. The Practice of English Language Teaching. Harlow: Longman, 1991.

Hubbard, P., H. Jones, B. Thornton, and R. Wheeler. A Training Course for TEFL. Oxford: Oxford UP, 1983.

Jenner, B. "Error Analysis: An Introduction for Teachers." Modern English Teacher, 9.2 (1976): 15-18.

Kelly, Louis G. Twenty-Five Centuries of Language Teaching. Rowley: Newbury House, 1969. 
Lado, R. Linguistics across Cultures: Applied Linguistics for Language Teachers. Michigan: $U$ of Michigan, 1957.

Larsen-Freeman, D. Techniques and Principles in Language Teaching. New York: Oxford UP, 1986.

Piñel, R., and C. Moreno. "Un acercamiento a la influencia de la lengua materna en el aprendizaje de una lengua extranjera.” Actas de las Jornadas de Didáctica de las Lenguas Extranjeras. Universidad de Murcia. Forthcoming.

Quirk, R., S. Greenbaum, G. Leech, and J. Svartvik. A Comprehensive Grammar of English. London and New York: Longman, 1985.

. Teaching Foreign Language Skills. Chicago: U of Chicago, 1968. and M. S. Temperley. A Practical Guide to the Teaching of English. New York: Oxford UP, 1978.

Richards, J. C. and T. S. Rodgers. Approaches and Methods in Language Teaching. Cambridge: Cambridge UP, 1986

Savignon, S. J. Communicative Competence: Theory and Classroom Practice. Reading: AddisonWesley, 1983.

Svartvik, J. Errata: Papers in Error Analysis. Lund: Gleerup, 1973.

Swan, M. “A Critical Look at the Communicative Approach 1 and 2.” ELT Journal 39.1 (1985): 2-12 and 39.2 (1985): 76-87.

. “Language Conundrums: Some Responses to My Cry for Help." ELT Journal 45.4 (1991): 328-34.

Titone, R. Teaching Foreign Languages: An Historical Sketch. Washington: Georgetown UP, 1968.

Widdowson, H. “Against Dogma: A Reply to Michael Swan." ELT Journal 39.3 (1985): 135-47. Wright, T. Roles of Teachers and Learners. Oxford: Oxford UP, 1987. 